\title{
Antiklimaks Revisi Pasal "Karet" UU ITE
}

Oleh: Pardomuan Gultom

(dimuat di Koran ANALISA edisi Kamis, 20 Mei 2021. Link e-paper

https://analisadaily.com/e-paper/2021-05-20/files/assets/basic-html/index.html\#12 )

Pada 15 Februari 2021 yang lalu, Presiden Jokowi berniat merevisi pasal-pasal "karet" yang terdapat pada Undang-Undang Informasi dan Transaksi Elektronik (UU ITE). Namun, jika diperhatikan dari 33 Rancangan Undang-Undang (RUU) yang masuk dalam daftar Prolegnas Prioritas 2021 yang disampaikan dalam Rapat Paripurna ke-15 pada tanggal 23 Maret 2021 yang lalu, UU ITE tidak menjadi agenda prioritas revisi.

Hal ini turut dipertegas oleh Menkopolhukam, Mahfud MD, pada tanggal 29 April 2021, bahwa tidak akan ada revisi UU ITE (detik, 29/4). Pihak pemerintah hanya membuat pedoman teknis kriteria implementasi dalam bentuk Surat Keputusan Bersama (SKB) tiga kementerian dan lembaga, yakni Menkominfo, Jaksa Agung, dan Kapolri.

Dalam terminologi hukum, pasal-pasal "karet" mulai sejak berlakunya Wetboek van Straftrecht (WvS) hingga Kitab Undang-Undang Hukum Pidana (KUHP) yang dijadikan sebagai pedoman dalam UU ITE yang mengandung delik ujaran kebencian, pencemaran nama baik, permusuhan, dan penghinaan terhadap pemerintah disebut dengan istilah Haatzai Artikelen.

\section{Haatzai Artikelen}

Adalah G. van Loon, seorang editor koran Het Niews van den Dag, dijatuhi hukuman penjara selama delapan hari oleh Pengadilan Batavia pada tahun 1914 karena tulisannya dianggap dapat menimbulkan kebencian di kalangan sesama penduduk Eropa di Hindia Belanda. Namun, pada Januari 1915, Pengadilan Tinggi Hindia Belanda membatalkan putusan tersebut karena pasal-pasal yang dikenakan kepada van Loon dianggap tidak berlaku bagi sesama golongan penduduk Eropa di Hindia Belanda. Perasaan anti-Jerman sangat kuat melanda kalangan orang-orang Belanda yang tinggal di Hindia Belanda muncul saat perang berkecamuk di Eropa pada awal abad ke-20 sehingga surat-surat kabar di Batavia dan Surabaya terpengaruh dan terseret untuk memuat percikan perasaan tersebut (Dijk, 2007). 
Padahal sasaran norma yang terkadung dalam pasal-pasal kebencian tersebut dibatasi hanya berlaku pada ungkapan untuk kelompok masyarakat yang berbeda, yakni golongan Eropa, Timur Asing, dan Bumiputera (Shidarta, 2018). Dengan pertimbangan tersebut, Pengadilan Tinggi Hindia Belanda membatalkan putusan Pengadilan Batavia terhadap van Loon.

Dalam konteks hukum masa kolonial, tindakan van Loon ini dianggap sebagai penyebaran rasa kebencian (Haatzai Artikelen). Pemerintah kolonial Belanda menganggap penyebaran rasa kebencian tersebut sebagai upaya memprovokasi masyarakat untuk menggoyahkan pemerintah kolonial Belanda ketika itu. Ujaran atau ungkapan rasa permusuhan, kebencian, dan penghinaan terhadap pemerintah selalu dipandang sebagai upaya menghalangi pemerintah dalam menjalankan fungsi tertib sosial tadi.

Haatzai Artikelen merupakan perspektif hukum warisan kolonial Belanda yang hingga kini dianggap sebagai ketentuan yang masih dipakai dalam Kitab Undang-Undang Hukum Pidana (KUHP) yang terdapat pada Pasal 134, 136 bis, 137 ayat (1), 154, 155, dan Pasal 156a dengan penekanan adanya penghinaan, kebencian, dan permusuhan kepada pemerintah atau golongan tertentu. Di masa Orde Baru, Pasal 154 dan Pasal 156 ini kedudukannya diperkuat dengan Putusan Mahkamah Agung Nomor 71 K/Kr/1973.

Secara historis, Haatzai Artikelen sendiri tidak berlaku dalam Kitab Undang-Undang Hukum Pidana (Wetboek van Straftrech) di Belanda. Seharusnya, apabila Hindia Belanda sebagai wilayah jajahan Belanda, maka dalam penerapan asas konkordansi dalam pembuatan dan penerapan hukum, apa yang diterapkan di Belanda juga berlaku di Hindia Belanda, termasuk Haatzai Artikelen.

Haatzai Artikelen ini, jika merujuk pada pendapat Prof. Simons tentang subjektivitas hukum pidana (Lamintang, 2019), merupakan hukum pidana subjektif (strafrecht in subjectieve zin) atau disebut ius puniendi, karena secara subjektif pemerintahan kolonial Belanda dimasa itu melaksanakan haknya untuk menghukum dengan mengaitkan pelanggaran terhadap peraturan. Sementara peraturan yang dibuatnya itu tidak atau tanpa melibatkan rakyat jajahan.

Sifat status quo negara dalam upaya pembaruan hukum nasional, khususnya terhadap pasalpasal "karet" Haatzai Artikelen belum menunjukkan niat yang baik. Hal ini tampak dari tetap 
dipertahankannya Haatzai Artikelen pada Undang-Undang No. 11 Tahun 2008 jo. UndangUndang No. 19 Tahun 2016 tentang Informasi dan Transaksi Elektronik (UU ITE), yakni Pasal 27 ayat (3) dan Pasal 45 ayat (1). Dalam Penjelasan Pasal 27 ayat (3), yang menjadi acuan pencemaran nama baik dan/atau fitnah adalah ketentuan yang diatur dalam KUHP, yakni Pasal 310-320 Buku Kedua (Kejahatan) Bab XVI tentang Penghinaan.

Catatan terhadap ketentuan Pasal 27 ayat (3) dan Pasal 45 ayat (1) UU ITE adalah tak ada definisi apa yang dimaksud dengan penghinaan atau pencemaran nama baik Hiariej, 2009). Karena itu, untuk menentukan apakah telah dipenuhinya unsur pencemaran nama baik harus merujuk Pasal 310 KUHP.

Selain itu, ada disparitas ancaman pidana cukup besar antara ketentuan Pasal 310 KUHP dan Pasal 45 Ayat 1 UU ITE. Terhadap pencemaran nama baik, Pasal 310 KUHP memberikan ancaman maksimum 9 bulan penjara atau denda tiga ratus rupiah. Bandingkan dengan ketentuan Pasal 45 Ayat 1 UU ITE yang mengancam pelaku dengan pidana penjara paling lama 6 tahun dan atau denda paling banyak 1 miliar rupiah.

\section{Gugatan Konstitusional}

Perlindungan dan pemenuhan hak-hak konstitusional warga negara telah diatur pada Pasal 28D ayat (1) UUD 1945 jo. Pasal 51 ayat (1) Undang-Undang No. 24 Tahun 2003 tentang Mahkamah Konstitusi. Dan secara internasional, hak konstitusional ini juga merupakan hak asasi manusia yang terdapat dalam Pasal 18, 19, 21, dan 22 Kovenan Internasional Hak-hak Sipil dan Politik (International Covenan on Civil and Political Rights/ICCPR).

Gugatan konstitusional terhadap pasal-pasal "karet” dalam KUHP telah berlangsung sejak tahun 2006. Setidaknya, MK telah memeriksa dan memutus 4 (empat) perkara terkait dengan pasalpasal tersebut, yaitu Putusan Nomor 013-022/PUU-IV/2006 (pengujian Pasal 134, Pasal 136 bis, dan Pasal 137 KUHP) yang diajukan oleh Eggi Sudjana dan Pandapotan Lubis, Putusan Nomor 6/PUUV/2007 (pengujian Pasal 107, Pasal 154, Pasal 155, Pasal 160, Pasal 161, Pasal 207, dan Pasal 208 KUHP) yang diajukan oleh Panji Utomo, Putusan Nomor 7/PUU-VII/2009 (pengujian Pasal 160 KUHP) yang diajukan oleh Rizal Ramli, dan Putusan Nomor 14/PUU-VI/2008 (pengujian Pasal 310 ayat (1) dan ayat (2), Pasal 311 ayat (1), Pasal 316, dan Pasal 207 KUHP) yang diajukan oleh Risang Bima Wijaya dan Bersihar Lubis. 
Mahkamah Konstitusi (MK) mengakui bahwa delik penghinaan yang seringkali dijatuhkan kepada warga negara Indonesia yang menggunakan hak konstitusionalnya untuk menyatakan pikiran dan pendapat, serta mereka yang melakukan aktivitas penyebarluasan informasi. Di samping itu juga, ketentuan tersebut mudah disalahgunakan oleh mereka yang tidak menyukai kemerdekaan menyatakan pikiran dan pendapat, kebebasan berekspresi, dan kebebasan pers.

\section{Asas Ultimum Remedium}

Pada hakikatnya hukum konstitusi merupakan hukum yang tertinggi di Indonesia. Hal ini didasari dari konsep Indonesia sebagai Negara Hukum (rechtstaat). Pencantuman sanksi pidana dalam undang-undang sebagai primum remedium sejatinya dapat mengakibatkan terlanggarnya hak-hak konstitusional warga negara Indonesia.

Mengutip pendapat dari H.G de Bunt dalam bukunya Strafrechtelijke Handhaving van Miliue Recht, hukum pidana dapat menjadi primum remidium jika korban sangat besar, tersangka/terdakwa merupakan recidivist, dan kerugian tidak dapat dipulihkan (irreparable). Kemudian disimpulkan oleh Remmelink, bahwa sangat jelas dan nyata sebagai sanksi yang tajam, hukum pidana hanya akan dijatuhkan apabila mekanisme penegakan hukum lainnya yang lebih ringan telah tiada berdaya guna atau tidak dipandang cocok.

Salah satu cara agar ketentuan dari undang-undang dapat dilaksanakan maka diaturlah materi yang memuat sanksi pidana dalam suatu undang-undang, sehingga dikatakan hukum pidana sebagai obat atau cara terakhir (ultimum remedium) agar suatu ketentuan dapat dipatuhi.

Hukum pidana seyogyanya ditempatkan sebagai instrumen terakhir (ultimum remedium) karena sejatinya hukum pidana merupakan hukum yang paling keras diantara instrumeninstrumen hukum lain yang mengontrol tingkah laku masyarakat. Selain itu, perlu dipahami bahwa penetapan sanksi pidana seyogyanya dilakukan secara terukur dan berhati-hati karena hal itu terkait dengan kebijakan peniadaan kemerdekaan dari hak asasi manusia yang dilegalisasi oleh undang-undang.

Menurut Sudikno Mertokusumo (2005), hukum yang berfungsi sebagai perlindungan kepentingan manusia dalam penegakannya harus memperhatikan 3 (tiga) unsur fundamental hukum, antara lain: kepastian hukum (Rechtssicherheit), kemanfaatan (Zweckmassigkeit) dan keadilan (Gerechtigkeit). Oleh karena itu, dalam menentukan pemberian sanksi pidana dalam 
suatu undang-undang perlu memperhatikan ketiga unsur fundamental hukum tersebut karena pada dasarnya itulah yang menjadi hakikat dari tujuan hukum.

Hal ini jelas tidak hanya melanggar prinsip teori hukum pidana sebagai ultimum remedium, juga telah melanggar hak konstitusional warga Negara karena penerapan ketentuan pidana penjara telah merampas hak-hak asasi yang melekat pada seseorang sebagaimana tercantum dalam Pasal 28D ayat (1) UUD 1945 yang menyatakan, "Setiap orang berhak atas pengakuan, jaminan, perlindungan dan kepastian hukum yang adil serta perlakuan yang sama di hadapan hukum".

Artinya penetapan suatu perbuatan itu dikategorikan suatu tindak pidana, maka perlu dilihat terlebih dahulu apakah perbuatan itu merupakan mala in se atau mala prohibita. Jika perbuatan itu termasuk kategori mala prohibita, maka penetapan status sebagai perbuatan pidana merupakan politik hukum terbuka (open legal policy) dari pembentuk undang-undang. Dengan demikian dalam membuat suatu produk hukum, seperti SKB 3 kementerian dan lembaga terkait pedoman teknis kriteria implementasi UU ITE kiranya konsepsi hukum pidana sebagai ultimum remedium dan konsepsi mala in se dan mala prohibita, dan konsepsi hak asasi manusia harus menjadi pertimbangan dalam membuat produk hukum yang humanis.

*Penulis adalah Mahasiswa konversi Sekolah Tinggi Ilmu Hukum (STIH) Graha Kirana/Alumnus Departemen Ilmu Politik FISIP USU 